\title{
Assessment of the Ti-Rich Corner of the Ti-Si Phase Diagram: The Recent Dispute About the Eutectoid Reaction
}

\author{
Marina Fiore ${ }^{a}$, Flavio Beneduce Neto ${ }^{a}$, Cesar Roberto de Farias Azevedo ${ }^{*}$ \\ ${ }^{a}$ Department of Metallurgical and Materials Engineering, Escola Politécnica, Universidade de São \\ Paulo - USP, Av. Professor Mello Moraes, 2463, 05508-030, São Paulo, SP, Brazil
}

Received: February 24, 2016; Revised: May 3, 2016; Accepted: June 5, 2016

\begin{abstract}
The thermodynamic optimization of Ti-Si-X systems requires that their respective binary systems are constantly updated. The Ti-Si system has been experimentally investigated since the 1950 s and these critical experimental data can be employed to calculate the Ti-Si phase diagram using thermodynamic modeling. The most recent assessment of the Ti-Si system was performed in 1998, showing the presence of stoichiometric $\mathrm{Ti}_{3} \mathrm{Si}$ as stable phase. In the light of the dispute over the stability of $\mathrm{Ti}_{3} \mathrm{Si}$ phase in the eutectoid reaction of the Ti-Si and Ti-X-Si systems, the present work assessed the Ti-rich corner of the "stable" (featuring $\mathrm{Ti}_{3} \mathrm{Si}$ phase) and "metastable" (featuring $\mathrm{Ti}_{5} \mathrm{Si}_{3}$ phase) Ti-Si phase diagrams. The phase boundaries, the values of the error of the least-square method of the optimization procedure and the relative standard deviation of the calculated variables of the assessed diagrams; and previous investigations were discussed in order to inspire further experimental work on the eutectoid reaction of the Ti-Si phase diagram.
\end{abstract}

Keywords: Ti-Si phase diagram, Ti-rich corner, thermodynamic modeling, sublattice model, eutectoid reaction

\section{Introduction}

There is a continuous technological interest in the Ti-Si system, which is promoted by the beneficial effect of $\mathrm{Si}$ addition on the oxidation and creep resistance (via solid solution and precipitation hardening) of Ti-X-Si alloys ${ }^{1}$. The earliest Ti-Si phase diagram was thoroughly investigated in 1952 by Hansen et al. ${ }^{2}$, which studied more than fifty Ti-Si binary alloys. The absence of interstitial contamination during the casting of these alloys was verified by hardness measurements of control samples of pure Ti. The microstructure was characterized by metallography and $\mathrm{X}$-ray diffraction, while the transition temperatures were determined by incipient melting point studies and thermal analysis. Their results showed that non-stoichiometric $\mathrm{Ti}_{5} \mathrm{Si}_{3}$ phase existed over a composition range from 38 to $40 \mathrm{at} \% \mathrm{Si}$. The phase diagram indicated in the Ti-rich corner the presences of a eutectic reaction at $1606 \mathrm{~K}, \mathrm{~L}$ $\rightarrow \mathrm{Ti}(\beta)+\mathrm{Ti}_{5} \mathrm{Si}_{3}$, and a eutectoid reaction at $1133 \mathrm{~K}, \mathrm{Ti}(\beta)$ $\rightarrow \mathrm{Ti}(\alpha)+\mathrm{Ti}_{5} \mathrm{Si}_{3}$. The presence of this eutectoid reaction was confirmed by the investigation of seven Ti-Si alloys containing up to $2 \% \mathrm{Si}$, which were heat-treated between $1023 \mathrm{~K}$ and $1373 \mathrm{~K}$ for times of respectively 170 and 31 hours. In 1954 Sutcliffe $^{3,4}$ investigated the Ti-rich corner of the Ti-Si system using isothermal heat-treatments of homogenized samples at temperatures between $923 \mathrm{~K}$ and $1373 \mathrm{~K}$ for 720 to 72 hours, respectively. Control samples and hardness measurements were also used to ensure that the interstitial content $(\mathrm{O}$ and $\mathrm{N})$ in the alloys was below $0.05 \mathrm{wt} \%$. They confirmed the presence of a eutectoid reaction at $1129 \mathrm{~K}, \mathrm{Ti}(\beta) \rightarrow \mathrm{Ti}(\alpha)+\mathrm{Ti}_{5} \mathrm{Si}_{3}$, but presenting smaller Si solubility $(\sim 40 \%)$ in the $\operatorname{Ti}(\beta)$ phase than previous result ${ }^{2}$.

*e-mail: c.azevedo@usp.br
In 1970, Svechnikov et al. ${ }^{5}$ proposed a new experimental version of the Ti-Si phase diagram with the presence of a stoichiometric $\mathrm{Ti}_{3} \mathrm{Si}$ phase (tetragonal, $\mathrm{Ti}_{3} \mathrm{P}$ crystal structure). They studied thirty Ti-Si alloys, which were analyzed by differential thermal analysis (DTA), metallography and X-ray diffraction. The experimental procedure did not explicitly describe the use of control samples to ensure the lack of interstitial contamination in the alloys. The stoichiometric $\mathrm{Ti}_{3} \mathrm{Si}$ phase was identified in Ti-rich samples after heat-treatment at $1273 \mathrm{~K}$ for 115 hours and $1493 \mathrm{~K}$ for 120 hours. The Ti-rich corner of the experimental phase diagram showed unusual phase boundaries, featuring, for instance, the presence of $\mathrm{Ti}_{3} \mathrm{Si}$ phase until the eutectic reaction, $\mathrm{L} \rightarrow \mathrm{Ti}(\beta)+\mathrm{Ti}_{5} \mathrm{Si}_{3}$, and the presence of atypical boundaries at $1443 \mathrm{~K}$, dividing into two regions the $\left[\mathrm{Ti}(\beta)+\mathrm{Ti}_{3} \mathrm{Si}\right]$ and $\left[\mathrm{Ti}_{3} \mathrm{Si}_{+}+\mathrm{Ti}_{5} \mathrm{Si}_{3}\right]$ phase fields, respectively. Finally they suggested the presence of two new reactions in the Ti-rich corner: a peritectoid reaction at $1444 \mathrm{~K}, \mathrm{Ti}(\beta)+\mathrm{Ti}_{5} \mathrm{Si}_{3} \rightarrow \mathrm{Ti}_{3} \mathrm{Si}$, and a eutectoid reaction at $1133 \mathrm{~K}, \mathrm{Ti}(\beta) \rightarrow \mathrm{Ti}(\alpha)+\mathrm{Ti}_{3} \mathrm{Si}$.

In 1977 and 1978 Aaronson et al. ${ }^{6,7}$ investigated the eutectoid reaction of the Ti-rich corner of the Ti-Si system, using continuous cooling experiments, microstructural characterization and microanalysis. Isothermal heat-treatments of homogenized samples were carried out at $1023 \mathrm{~K}$ for 24 and 120 hours. Chemical analysis of interstitials $(\mathrm{C}, \mathrm{O}, \mathrm{N}$, and $\mathrm{H}$ ) after the homogenization heat-treatment indicated that their alloys contained approximately $0.04 \mathrm{wt} \% \mathrm{C}, 250$ to $350 \mathrm{ppm}$ of $\mathrm{O}_{2}, 65 \mathrm{ppm}$ of $\mathrm{H}_{2}$ and $200 \mathrm{ppm}$ of $\mathrm{N}_{2}$. None of the previous works ${ }^{2-5}$ actually used chemical analysis to check the amount of interstitials in the investigated alloys. The authors did not observe any precipitation of $\mathrm{Ti}_{3} \mathrm{Si}$ phase, as proposed by Svechnikov et al..$^{5}$, confirming, instead, the presence of a eutectoid reaction at $1148 \mathrm{~K}, \operatorname{Ti}(\beta) \rightarrow \operatorname{Ti}(\alpha)$ $+\mathrm{Ti}_{5} \mathrm{Si}_{3}$, as observed by previous investigations ${ }^{2-4}$. Their results also featured higher $\mathrm{Si}$ solubility in the $\mathrm{Ti}(\beta)$ phase 
and lower Si solubility in the $\operatorname{Ti}(\alpha)$ than previous works ${ }^{3,4}$. Plitcha and Aaronson ${ }^{6,7}$ concluded that the differences between their version of the eutectoid reaction of the Ti-Si system and previous results could be due to the higher impurity contents in the alloys previously investigated.

The first thermodynamic assessment of the Ti-Si phase diagram was performed by Kaufmann ${ }^{8}$ in 1976. This assessment was based on the experimental results of Hansen et al. ${ }^{2}$, but considering the $\mathrm{Ti}_{5} \mathrm{Si}_{3}$ phase as a stoichiometric intermetallic. Kaufmann ${ }^{8}$ did not provide any information about the optimization procedure and his calculated diagram was a simplistic version of previous experimental phase diagrams ${ }^{2-4}$. Murray ${ }^{9}$ in 1987 assessed the Ti-Si system and the assessed phase diagram ${ }^{9}$ was in fair agreement with the experimental results of Svechnikov et al. ${ }^{5}$, showing the presences of a peritectoid reaction at $1443 \mathrm{~K}, \mathrm{Ti}(\beta)+\mathrm{Ti}_{5} \mathrm{Si}_{3} \rightarrow \mathrm{Ti}_{3} \mathrm{Si}$, and a eutectoid reaction at $1138 \mathrm{~K}, \mathrm{Ti}(\beta) \rightarrow \mathrm{Ti}(\alpha)+\mathrm{Ti}_{3} \mathrm{Si}$. Additionally, the phase diagram featured the presence of non-stoichiometric $\mathrm{Ti}_{5} \mathrm{Si}_{3}$ phase. In 1989 Vahlas et al. ${ }^{10}$ assessed the Ti-Si system and their calculated diagram showed a much simpler version of previous assessment ${ }^{9}$, featuring the presence of $\mathrm{Ti}_{5} \mathrm{Si}_{3}$ phase as a stoichiometric intermetallic.

In 1996 Seifert et al. ${ }^{11}$ employed software using Gaussian least square optimization method for the determination of the adjustable optimizing variables of the thermodynamic functions to assess the Ti-Si system. They tested two different thermodynamic descriptions for the liquid phase: the regular solution model using the Redlich-Kister formalism; and the partially ionic liquid model. Their calculated phase diagram was in fair agreement with the calculated diagram proposed by Murray ${ }^{9}$ and the experimental diagram proposed by Svechnikov et al. ${ }^{5}$, indicating in the Ti-rich corner of phase diagram the presences of a peritectoid reaction at $1443 \mathrm{~K}, \mathrm{Ti}(\beta)+\mathrm{Ti}_{5} \mathrm{Si}_{3} \rightarrow \mathrm{Ti}_{3} \mathrm{Si}$, and a eutectoid reaction at $1138 \mathrm{~K}, \mathrm{Ti}(\beta) \rightarrow \mathrm{Ti}(\alpha)+\mathrm{Ti}_{3} \mathrm{Si}$. The authors did not use the experimental results of Aaronson and Plitcha ${ }^{6,7}$ for the eutectoid reaction, which did not confirm the presence of $\mathrm{Ti}_{3} \mathrm{Si}$ phase. Additionally, they did not find in the literature any experimental data for the $\operatorname{Si}$ solubility in the $\operatorname{Ti}(\alpha)$ and $\operatorname{Ti}(\beta)$ phases of the eutectoid reaction, $\operatorname{Ti}(\beta) \rightarrow \operatorname{Ti}(\alpha)+\mathrm{Ti}_{3} \mathrm{Si}$, so they assumed that the Si solubility in these phases was equal to previous experimental results ${ }^{2}$ for the "metastable" eutectoid reaction, $\mathrm{Ti}(\beta) \rightarrow \mathrm{Ti}(\alpha)+\mathrm{Ti}_{5} \mathrm{Si}_{3}$.

Concerning the dispute over the stability of the $\mathrm{Ti}_{3} \mathrm{Si}$ phase in Ti-Si and Ti-Al-Si alloys, Azevedo et al.,12-14 investigated in 1996 the Ti-rich corner of the Ti-Al-Si system using control samples (hardness measurements), TEM, EDS and electron diffraction. Their results did not show the presence of $\mathrm{Ti}_{3} \mathrm{Si}$ phase after isothermal heat-treatment at $973 \mathrm{~K}$ for 36 days, but the presence of a ternary non-stoichiometric $\mathrm{Ti}_{5} \mathrm{Si}_{3}$ phase. In 1997, Bulanova et al. ${ }^{15}$ also could not identify the presence of $\mathrm{Ti}_{3} \mathrm{Si}$ phase in Ti-13.5Si alloy after heat-treatments at $1323 \mathrm{~K}$ for 45 hours and $1023 \mathrm{~K}$ for 58 hours by XRD and microanalysis. The presence of $\mathrm{Ti}_{3} \mathrm{Si}$ phase in a $\mathrm{Ti}-13.5 \mathrm{Si}$ alloy was observed by Ramos et al. ${ }^{16}$ in 2006 after isothermal heattreatments at $1273 \mathrm{~K}$ and $1373 \mathrm{~K}$ for 90 hours by SEM-EDS analysis. In 2010 Costa et al. ${ }^{17}$ observed the presence of $\mathrm{Ti}_{3} \mathrm{Si}$ phase in Ti-13Si and Ti-20Si alloys after isothermal heat-treatment at $1273 \mathrm{~K}$ for various times by XRD. In $2014 \mathrm{Li}$ et al. ${ }^{18}$ observed the presence of $\mathrm{Ti}_{3} \mathrm{Si}$ phase in a Ti-15Si-5Al alloy after isothermal heat-treatment for 45 days at $973 \mathrm{~K}$ using microanalysis coupled with XRD. Finally, in 2014 Kozlov et al. ${ }^{19}$ observed the presence of $\mathrm{Ti}_{3} \mathrm{Si}$ phase in $\mathrm{Ti}-\mathrm{Si}$ and $\mathrm{Ti}-\mathrm{Ge}-\mathrm{Si}$ alloys after isothermal treatments of at $943 \mathrm{~K}$ for 720 hours by XRD.

Colinet and Tedenac ${ }^{20}$ studied in 2010 the structural stability of intermetallic phases in the Ti-Si system by abinitio calculations. A statistical model was used to obtain the enthalpy for the formation of the intermetallic phases. The predicted ground-state structures were consistent with those known to be stable at low temperature, except for the $\mathrm{Ti}_{3} \mathrm{Si}$ phase with $\mathrm{Ti}_{3} \mathrm{P}(\mathrm{tP} 32)$ structure, whose enthalpy of formation at $0 \mathrm{~K}(-47.11 \mathrm{~kJ} / \mathrm{mol}$ of atoms) was slightly above the ground-state line, indicating that the question of stability of the $\mathrm{Ti}_{3} \mathrm{Si}$ phase shown by previous experimental ${ }^{5}$ and calculated ${ }^{9,11} \mathrm{Ti}-\mathrm{Si}$ phase diagrams was in fact "controversial". More recently, Poletaev et al. ${ }^{21}$ indicated that $\mathrm{Ti}_{5} \mathrm{Si}_{3}$ phase was actually more stable than $\mathrm{Ti}_{3} \mathrm{Si}$ phase at $0 \mathrm{~K}$ by ab initio calculations. They also confirmed the presence of $\mathrm{Ti}(\alpha)$ and $\mathrm{Ti}_{5} \mathrm{Si}_{3}$ phases by electron diffraction and microanalysis after the heat-treatment of a Ti-0.7Si alloy at $873 \mathrm{~K}$ for 10 hours.

In the light of the dispute over the stability of $\mathrm{Ti}_{3} \mathrm{Si}$ phase in Ti-X-Si engineering alloys ${ }^{2-21}$, the present work will calculate and compare the Ti-rich corner of the "stable" and "metastable" Ti-Si phase diagrams, by assuming that $\mathrm{Ti}_{3} \mathrm{Si}$ is the stable phase in the eutectoid reaction, $\mathrm{Ti}(\beta) \rightarrow \mathrm{Ti}(\alpha)+\mathrm{Ti}_{3} \mathrm{Si}$. These results will be discussed in order to inspire further experimental work on critical regions of the Ti-Si phase diagram ${ }^{11}$.

\section{Methodology}

The present work calculated the stable and metastable Ti-Si phase diagrams (assuming that $\mathrm{Ti}_{3} \mathrm{Si}$ is the stable phase in the eutectoid reaction, $\left.\mathrm{Ti}(\beta) \rightarrow \mathrm{Ti}(\alpha)+\mathrm{Ti}_{3} \mathrm{Si}\right)$, using Thermocalc software and COST 507 (Thermochemical Database for Light Metal Alloys) ${ }^{22}$, whose principle objective was to provide a computerized thermodynamic database to permit the calculation of multicomponent phase equilibria for light alloys based on aluminum, magnesium and titanium to aid in the development of commercial light alloys under the organization of the European Cooperation in Science and Technology.

The liquid phase; and $\operatorname{Ti}(\alpha)$ and $\operatorname{Ti}(\beta)$ solid solution phases were described using Equations 1 to 5 (see Annex 1). The Gibbs free energy of reference $\left(G^{\text {ref }}\right)$ describes the mechanical mixing of pure elements (see equation 2 ), while the Gibbs free energy of the ideal solution $\left(\mathrm{G}^{\mathrm{id}}\right)$ was described by equation 3 and the excess Gibbs free energy $\left(\mathrm{G}^{\mathrm{ex}}\right)$ was described using the Redlich-Kister polynomial (see Equations 4 and 5) ${ }^{23}$. The Gibbs energy for the formation of stoichiometric $\mathrm{Ti}_{3} \mathrm{Si}$ phase was described using the Kopp-Neumann rule ${ }^{23}$, see Equation 6 and a more detailed description is given in Annex 1.

$$
\begin{gathered}
G_{\text {phase }}=G^{r e f}+G^{i d}+G^{e x} \\
G^{r e f}=x_{S i} \cdot G_{S i}^{r e f}+x_{T i} \cdot G_{T i}^{r e f}
\end{gathered}
$$


Where: $G_{i}^{r e f}=G_{i}^{S E R}$ and $x_{S i}$ and $x_{T i}$ are the molar fraction of the elements. The superscript 'SER'refers to the Standard Element Reference state.

$$
\begin{gathered}
G^{\text {id }}=R \cdot T \cdot\left[x_{S i} \cdot \ln x_{S i}+x_{T i} \cdot \ln x_{T i}\right] \\
G^{e x c}=x_{S i} \cdot x_{T i} \cdot L_{p h a s e}
\end{gathered}
$$

Where: $L_{\text {phase }}^{i}$ is the Ti-Si interaction parameter.

$$
\begin{gathered}
L_{\text {phase }}=L_{\text {phase }}^{0}+L_{\text {phase }}^{1}\left(x_{S i}-x_{T i}\right)+\ldots+L_{\text {phase }}^{v}\left(x_{S i}-x_{T i}\right)^{v} \\
\text { Where: }{ }^{L_{\text {phase }}^{v}}=a+b T+\ldots \\
G_{T i_{3} S i}^{\text {form }}-x_{T i} \cdot G_{T i}^{S E R}-x_{S i} \cdot G_{S i}^{S E R}=a+b \cdot T+c \cdot T \cdot \ln (T)
\end{gathered}
$$

The non-stoichiometric $\mathrm{Ti}_{5} \mathrm{Si}_{3}$ phase was described by the Compound Energy Formalism ${ }^{23}$, using a three sublattices configuration, $(\mathrm{Ti}, \mathrm{Si})_{2}(\mathrm{Si}, \mathrm{Ti})_{3}(\mathrm{Ti})_{3}$ (see Equations 7 to 10 ) as suggested previously ${ }^{11}$. These authors ${ }^{11}$ described the $\mathrm{Ti}_{5} \mathrm{Si}_{3}$ phase as a non-stoichiometric compound containing three sublattices to represent its $\mathrm{D} 8_{8}$ crystal structure - 4 atoms of $\mathrm{Ti}$ in the position 4(d), 6 atoms of Ti in the position $6(\mathrm{~g})$ and 6 atoms of $\mathrm{Si}$ in the position $6(\mathrm{~g}):(\mathrm{Ti}, \mathrm{Si})_{2}:(\mathrm{Si}, \mathrm{Ti})_{3}:(\mathrm{Ti})_{3}$. Colinet and $T$ dedenac $^{20}$, for instance, used a four sublattices configuration to describe the $\mathrm{Ti}_{5} \mathrm{Si}_{3}$ phase in order to account for the $\mathrm{D} 8_{8}$ structure and for the possibility of inserting $\mathrm{Si}$ atoms in the $2 \mathrm{~b}$ Wyckoff positions of $\mathrm{P}_{3} / \mathrm{mcm}$ space group. The use of a four sublattices $\left((\mathrm{Si}, \mathrm{Ti})^{\alpha}(\mathrm{Ti})^{\mathrm{bl}}(\mathrm{Ti})^{\mathrm{b2}}(\mathrm{V}, \mathrm{Si})^{\gamma}\right)$ to describe the $\mathrm{Ti}_{5} \mathrm{Si}_{3}$ phase ${ }^{20}$ was not considered in the present work as it might significantly increase the number of excess terms to be calculated during the optimization procedure of higher order systems.

The parameters used of the thermodynamic description of the $\mathrm{Ti}_{5} \mathrm{Si}_{3}$ and $\mathrm{Ti}_{3} \mathrm{Si}$ phases in the present work are listed in Table 1 and more detailed thermodynamic description of the phases is given in Annex1. Note that the value for the Gibbs energy for the formation of Ti phase with $\mathrm{D} 8_{8}$ crystal structure was not calculated in the present work, so the value listed for this parameter was directly copied from the COST 507 thermochemical database ${ }^{22}$.

$$
\begin{aligned}
& G^{T i 5 S i 3}={ }^{\text {form }} G^{T i 5 S i 3}+{ }^{i d} G^{T i 5 S i 3}+{ }^{e x} G^{T i 5 S i 3} \\
& { }^{\text {form }} G^{T i s i 3}=y_{T i}^{\prime} \cdot y_{T i}^{\prime \prime} \cdot G_{T i: T i: T i}^{r e f}+y_{T i}^{\prime} \cdot y_{S i}^{\prime \prime} \cdot G_{T i: S i: T i}^{r e f}+ \\
& y_{S i}^{\prime} \cdot y_{S i}^{\prime \prime} \cdot G_{S i: S i: T i}^{r e f}+y_{S i}^{\prime} \cdot y_{T i}^{\prime \prime} \cdot G_{S i: T i: T i}^{r e f} \\
& { }^{i d} G^{T_{i j} S_{i 3}}=R \cdot T \cdot\left(\begin{array}{l}
2 \cdot\left[y_{T i}^{\prime} \cdot \ln \left(y_{T i}^{\prime}\right)+y_{S i}^{\prime} \cdot \ln \left(y_{S i}^{\prime}\right)\right]+ \\
3 \cdot\left[y_{T i}^{\prime \prime} \cdot \ln \left(y_{T i}^{\prime \prime}\right)+y_{S i}^{\prime \prime} \cdot \ln \left(y_{S i}^{\prime \prime}\right)\right]
\end{array}\right) \\
& { }^{e x} G^{T i s S i 3}=y_{T i}^{\prime} \cdot y_{S i}^{\prime} \cdot\left(y_{T i}^{\prime \prime} \cdot{ }^{0} L_{T i, S i: T i: T i}^{T i s i 3}+y_{S i}^{\prime \prime} \cdot{ }^{0} L_{T i, S i: S i: T i}^{T i s i s i 3}\right)+ \\
& y_{T i}^{\prime \prime} \cdot y_{S i}^{\prime \prime} \cdot\left(y_{T i}^{\prime} \cdot{ }^{0} L_{T i: S i, T i T i}^{T i_{S} S_{3}}+y_{S i}^{\prime} \cdot{ }^{0} L_{S i: S i, T i: T i}^{T i_{i} S i_{3}}\right)
\end{aligned}
$$

Where: $y_{j}^{(n)}$ is the site fraction of the element $(j)$ in the sublattice (n).

The Parrot module of the Thermocalc software was used for the determination of the optimizing variables of the thermodynamic functions describing $\mathrm{Ti}_{3} \mathrm{Si}$ and $\mathrm{Ti}_{5} \mathrm{Si}_{3}$ phases, using selected experimental data, including the invariant reactions shown in Table 2 . The experimental data for the eutectoid temperature and the $\mathrm{Si}$ solubility in the $\operatorname{Ti}(\alpha)$ and $\operatorname{Ti}(\beta)$ phases in the "stable" eutectoid reaction, $\operatorname{Ti}(\beta) \rightarrow \operatorname{Ti}(\alpha)$ $+\mathrm{Ti}_{3} \mathrm{Si}$, was estimated based on previous experimental results ${ }^{2}$ for the "metastable" eutectoid reaction, $\operatorname{Ti}(\beta) \rightarrow \operatorname{Ti}(\alpha)+$ $\mathrm{Ti}_{5} \mathrm{Si}_{3}$, using adjustment factors for correcting the values of the eutectoid temperature and the Si solubility in the $\operatorname{Ti}(\alpha)$ and $\operatorname{Ti}(\beta)$ phases. These factors were based in the changes of the eutectoid temperature and $\mathrm{C}$ solubility of the $\mathrm{Fe}(\gamma)$ and $\mathrm{Fe}(\alpha)$ phases in the $\mathrm{Fe}-\mathrm{C}$ phase diagram for the stable, $\mathrm{Fe}(\gamma, 2.97 \% \mathrm{C}) \rightarrow \mathrm{Fe}(\alpha, 0.096 \% \mathrm{C} \%)+\mathrm{C}$ (graphite) at $740^{\circ} \mathrm{C}$, and metastable, $\mathrm{Fe}(\gamma, 3.46 \% \mathrm{C}) \rightarrow \mathrm{Fe}(\alpha, 0.104 \%)+\mathrm{Fe}_{3} \mathrm{C}$ at $727^{\circ} \mathrm{C}$, eutectoid reactions ${ }^{24}$. The absolute error in the experimental values was assumed to be equal to $10 \mathrm{~K}$ for the incongruent temperatures; and between 0.02 and 0.001 for the Si solubility,

(atomic fraction of Si). Finally, the same weight was attributed to all the experimental data used in the present assessment. Table 3 shows the values for the enthalpy for the formation of intermetallic phases used in the present investigation ${ }^{11,20,25-30}$. Colinet and Tedenac ${ }^{20}$, for instance, obtained the values of the enthalpy for the formation of the intermetallic phases at $0 \mathrm{~K}$ via ab-initio calculations and statistical modelling.

The missing variables of the $\mathrm{Ti}_{5} \mathrm{Si}_{3}$ phase (see Table 1) were initially calculated during the optimization procedure of the metastable Ti-Si phase diagram (by suspending the presence of the $\mathrm{Ti}_{3} \mathrm{Si}$ phase). These calculated values were fixed for the calculation of the missing variables of the $\mathrm{Ti}_{3} \mathrm{Si}$ phase during the optimization of the stable Ti-Si phase diagram.

\section{Results and discussion}

The calculated values of the variables used for the description of $\mathrm{Ti}_{3} \mathrm{Si}$ and $\mathrm{Ti}_{5} \mathrm{Si}_{3}$ phases of the present work were compared with the values calculated by Seifert et al. ${ }^{11}$, using the regular model for describing the liquid phase. This comparison showed the same order of magnitude for most calculated variables (see Table 4). The main differences were observed for V31 (used for the description of the Gibbs energy for the formation of hypothetic $\mathrm{Ti}_{6} \mathrm{Si}_{2}$ phase); and $\mathrm{V} 1$ and V2 (used for the description of the Gibbs energy for the formation $\mathrm{Ti}_{3} \mathrm{Si}$ phase) variables. Additionally, the present investigation used three variables, instead of two variables, to describe the $\mathrm{Ti}_{3} \mathrm{Si}$ phase. According to Thermo-Calc data optimization user guide version $2015 \mathrm{a}^{31}$, values of Vi1-type variables around $10^{5}$ might indicate that either there were too many variables describing the $\mathrm{Ti}_{5} \mathrm{Si}_{3}$ and $\mathrm{Ti}_{3} \mathrm{Si}$ phases or that the user did not set "proper weights" on the experimental data during the optimization procedure. Additionally, the same source ${ }^{31}$ stated that Vi2-type variables should not present values in the order of 10 or more, as this may lead to either the presence of "inverted miscibility gaps" or the re-stabilization of a phase at high temperature. In the present assessment just one out of six Vil- variables presented value below $10^{5}$ (see Table 4); while half of the Vi2-type variables presented values below the order of 10. Finally, the optimization procedures for the calculation of the stable and metastable phase diagrams showed values for the reduced sum of squares approximately equal to 10 , which are above the recommended value of one ${ }^{31}$. These results suggest that 
Table 1: Parameters and variables used for the thermodynamic description of the $\mathrm{Ti}_{5} \mathrm{Si}_{3}$ and $\mathrm{Ti}_{3} \mathrm{Si}$ phases. Vil in ( $\left.\mathrm{J} .(\mathrm{mol} \text { of atoms })^{-1}\right)$; Vi2 and $\mathrm{Vi3}$ in $\left.\left(\mathrm{J} .(\mathrm{mol} \text { of atoms })^{-1}\right) \cdot \mathrm{K}^{-1}\right)$.

\begin{tabular}{|c|c|c|}
\hline Thermodynamic description & Parameters & Optimizing variables \\
\hline $\begin{array}{l}\text { Gibbs energy for the formation of hypothetic } \mathrm{Ti}_{3} \mathrm{Si}_{5} \\
\text { (D88 crystal structure) }\end{array}$ & ${ }^{0} G_{S i: S i: T i}^{T i S_{i j}}-\left[3 \cdot G_{T i}^{h c p}(T)+5 \cdot G_{S i}^{\text {diamond }}(T)\right]$ & $V 11+V 12 . T$ \\
\hline $\begin{array}{l}\text { Gibbs energy for the formation of } \mathrm{Ti}_{5} \mathrm{Si}_{3}\left(\mathrm{D} 8_{8} \text { crystal }\right. \\
\text { structure) }\end{array}$ & ${ }^{0} G_{T i: S i: T i}^{T i_{i} S i_{3}}-\left[5 \cdot G_{T i}^{h c p}(T)+3 \cdot G_{S i}^{\text {diamond }}(T)\right]$ & $V 21+V 22 . T$ \\
\hline $\begin{array}{l}\text { Gibbs energy for the formation of hypothetic } \mathrm{Ti}\left(\mathrm{D} 8_{8}\right. \\
\text { crystal structure) }\end{array}$ & ${ }^{0} G_{T i: T: T i: T i}^{T T_{i} S_{i}}-\left[8 \cdot G_{T i}^{h c p}(T)\right]$ & $(40000+20 . T)$ \\
\hline $\begin{array}{l}\text { Gibbs energy for the formation of hypothetic } \mathrm{Ti}_{6} \mathrm{Si}_{2} \\
\text { (D8 } 8_{8} \text { crystal structure) }\end{array}$ & ${ }^{0} G_{S i: T i: T i}^{T i S i i_{i}}-\left[6 \cdot G_{T i}^{h c p}(T)+2 \cdot G_{S i}^{\text {diamond }}(T)\right]$ & $V 31+V 32 . T$ \\
\hline Excess Gibbs energy for the interaction Ti: Si,Ti:Ti & ${ }^{0} L_{T i: S i, T i: T i}^{T i i_{5} S i_{3}}$ & $V 41+V 42 . T^{*}$ \\
\hline Excess Gibbs energy for the interaction Si: Si,Ti:Ti & ${ }^{0} L_{S i: S i, T i: T i}^{T i i_{5} S i_{3}}$ & $V 41+V 42 . T^{*}$ \\
\hline Excess Gibbs energy for the interaction Ti,Si:Ti:Ti & ${ }^{0} L_{T i, S i: T i: T i}^{T i i_{S} S i 3}$ & $V 51+V 52 . T^{*}$ \\
\hline Excess Gibbs energy for the interaction Ti,Si:Si:Ti & ${ }^{0} L_{T i, S i: S i: T i}^{T i S i 3}$ & $V 51+V 52 . T^{*}$ \\
\hline Gibbs energy for the formation of stoichiometric $\mathrm{Ti}_{3} \mathrm{Si}$ & ${ }^{0} G_{T i: S i}^{T i z S i}-\left[3 \cdot G_{T i}^{h c p}(T)+G_{S i}^{\text {diamond }}(T)\right]$ & $V 1+V 2 . T+V 3 \cdot T \cdot \ln T$ \\
\hline
\end{tabular}

the further experimental data and better modeling of the liquid phase are needed to improve the assessment of the present Ti-Si phase diagram. Seifert et al. ${ }^{11}$, for instance, also used the partially ionic liquid model to describe the liquid phase and their results apparently showed a better fit between the calculated and the experimental results for most of the reactions involving the liquid phase when compared to their results using the regular solution model to describe the liquid phase.

Table 5 compares the experimental and the calculated equilibriums obtained in the present assessment for the stable and metastable Ti-Si phase diagrams. Five out of 37 calculated values presented a relative deviation above $5 \%$ when compared to the experimental values. Most of these deviations were originated in the equilibriums involving the liquid phase, such as the $\mathrm{L} \rightarrow$ $\beta+\mathrm{Ti}_{5} \mathrm{Si}_{3}$ reaction, which presented a deviation of $20 \%$ for the value of the $\mathrm{Si}$ solubility in $\operatorname{Ti}(\beta)$ phase and a value of $9.5 \%$ for the Si solubility in the liquid phase. These deviations involving the liquid phase might be decreased by using more complex models for the thermodynamic description of the liquid phase, such as the ionic two-sublattice liquid model; the associate liquid model; or the quasi-chemical model ${ }^{23}$. The remaining deviation values above $5 \%$ were found in the stable diagram, more specifically in following reactions:

- $\quad$ the peritectoid reaction, $\beta+\mathrm{Ti}_{5} \mathrm{Si}_{3} \rightarrow \mathrm{Ti}_{3} \mathrm{Si}$, which presented a deviation of $30 \%$ for the Si solubility in the $\operatorname{Ti}(\beta)$ phase;

- the eutectoid reaction, $\beta \rightarrow \alpha+\mathrm{Ti}_{3} \mathrm{Si}$, which presented a deviation of $7.5 \%$ for the Si solubility in the $\operatorname{Ti}(\alpha)$ phase.

These results indicate that there is a vital need for obtaining more reliable experimental data in these critical regions. For instance, the experimental results of the peritectoid reaction are still based on the work of Svechnikov et al. ${ }^{5}$ made in the 70 's. Additionally, the experimental data for the stable eutectoid reaction, $\beta \rightarrow \alpha+\mathrm{Ti}_{3} \mathrm{Si}$, and their respective $\mathrm{Ti}(\alpha)$ and $\operatorname{Ti}(\beta)$ solvus lines were not found in the literature ${ }^{5,11}$.

The calculated values of the enthalpy and the entropy of the formation of the intermetallic phases in the Ti-Si system are shown in Table 6 and Figures 1-a and 1-b. The calculated values of enthalpy are in fair agreement with the values found in the literature ${ }^{11,20,25-30}$, especially for the intermetallics phases in the Ti-rich corner, such as the $\mathrm{Ti}_{5} \mathrm{Si}_{3}$ and $\mathrm{Ti}_{3} \mathrm{Si}$ phases. Figure 1-a shows the enthalpies of the formation of the Si-Ti compounds, comparing the present and previous results ${ }^{11,20,25-30}$. This comparison confirmed a better agreement of the enthalpy values in the Ti-rich corner $\left(\mathrm{Ti}_{3} \mathrm{Si}\right.$ and $\mathrm{Ti}_{5} \mathrm{Si}_{3}$ phases). According to Kematick and Meyers ${ }^{28}$, the highest melting point for the compound in a system usually coincides which the position of the most negative value of the enthalpy (such as the $\mathrm{Ti}_{5} \mathrm{Si}_{4}$ phase, in according with Figure 1-a and Table 6). Figure 2-a, however, indicates that the highest melting point for the compound in the calculated Ti-Si diagram is found for the $\mathrm{Ti}_{5} \mathrm{Si}_{3}$ phase. Figure 1-b shows the entropy of the formation of the $\mathrm{Si}-\mathrm{Ti}$ compounds, featuring a maximum value of entropy for the $\mathrm{Ti}_{3} \mathrm{Si}$ phase, but this type of entropy curve could not be found in the literature in order to be compared with the present results.

Figure 2-a shows a general view of the calculated stable Ti-Si phase diagram, indicating that the positions of the phase boundaries are in fair agreement with previous assessment ${ }^{11}$. Figure 2-b shows a detail of the Ti-rich corner of the stable Ti-Si phase diagram near the eutectoid reaction, $\beta \rightarrow \alpha+\mathrm{Ti}_{3} \mathrm{Si}$, indicating that there is a lack of experimental data concerning the positions of the $\operatorname{Ti}(\alpha)$ and $\operatorname{Ti}(\beta)$ solvus lines. Figure 2-c compares the present assessment with the calculated Ti-Si phase diagram using the COST 507 database ${ }^{22}$ in the region of the eutectoid reaction. The present assessment shows lower values for the $\operatorname{Si}$ solubility in the $\operatorname{Ti}(\alpha)$ and $\operatorname{Ti}(\beta)$ phases, especially for the $\operatorname{Ti}(\beta)$ phase. 
Table 2: Experimental data for the invariant reactions used for the calculation of the "stable" and "metastable" Ti-Si phase diagrams ( $X_{\text {phase }}^{\text {: }}$ atomic fraction of Si in the phase).

\begin{tabular}{|c|c|c|c|}
\hline \multirow{3}{*}{$\begin{array}{l}\text { Reaction } \\
\mathrm{L}=\mathrm{Ti}_{5} \mathrm{Si}_{3}\end{array}$} & \multicolumn{2}{|c|}{ Experimental values } & \multirow{2}{*}{$\begin{array}{c}\text { References } \\
{[2-5]}\end{array}$} \\
\hline & $\mathrm{T}(\mathrm{K})$ & 2403 & \\
\hline & $\mathrm{X}_{\mathrm{Si}}$ & 0.375 & {$[2-5]$} \\
\hline \multirow{2}{*}{$\mathrm{L}=\mathrm{TiSi}_{2}$} & $\mathrm{~T}(\mathrm{~K})$ & 1773 & {$[2-5]$} \\
\hline & $\mathrm{X}_{\mathrm{Si}}$ & 0.667 & {$[2-5]$} \\
\hline \multirow{4}{*}{$\mathrm{L}=\beta+\mathrm{Ti}_{5} \mathrm{Si}_{3}$} & $\mathrm{~T}(\mathrm{~K})$ & 1613 & {$[2-5]$} \\
\hline & $\mathrm{X}_{\mathrm{Si}}^{\mathrm{L}}$ & 0.137 & {$[2,5]$} \\
\hline & $\mathrm{X}_{\mathrm{Si}}^{\beta}$ & $0.05 * *$ & [11] \\
\hline & $\mathrm{X}_{\mathrm{Si}}^{\mathrm{Ti}_{\mathrm{i}} \mathrm{Si}_{3}}$ & $0.36 * *$ & [11] \\
\hline \multirow{4}{*}{$\mathrm{L}=\mathrm{TiSi}_{2}+\mathrm{Si}$} & $\mathrm{T}(\mathrm{K})$ & 1603 & {$[2-5]$} \\
\hline & $\mathrm{X}_{\mathrm{Si}}^{\mathrm{L}}$ & 0.86 & {$[2-5]$} \\
\hline & $\mathrm{X}_{\mathrm{Si}^{\mathrm{Ti}} \mathrm{is}_{2}}$ & 0.667 & {$[2-5]$} \\
\hline & $\mathrm{X}_{\mathrm{Si}}^{\mathrm{Si}}$ & 1 & {$[2-5]$} \\
\hline \multirow{4}{*}{$\mathrm{L}=\mathrm{TiSi}_{2}+\mathrm{TiSi}$} & $\mathrm{T}(\mathrm{K})$ & 1743 & {$[2-5]$} \\
\hline & $\mathrm{X}_{\mathrm{Si}}^{\mathrm{L}}$ & 0.641 & {$[2-5]$} \\
\hline & $\mathrm{X}_{\mathrm{Si}}^{\mathrm{Tisi}}$ & 0.5 & {$[2-5]$} \\
\hline & $\mathrm{X}_{\mathrm{Si}}^{\mathrm{T} \mathrm{Si}_{\mathrm{i}}}$ & 0.667 & {$[2-5]$} \\
\hline \multirow{4}{*}{$\mathrm{L}+\mathrm{Ti}_{5} \mathrm{Si}_{3}=\mathrm{Ti}_{5} \mathrm{Si}_{4}$} & $\mathrm{~T}(\mathrm{~K})$ & 2193 & {$[2-5]$} \\
\hline & $\mathrm{X}_{\mathrm{Si}}^{\mathrm{L}}$ & 0.48 & {$[2-5]$} \\
\hline & $\mathrm{X}_{\mathrm{Si}}^{\mathrm{Ti}_{\mathrm{i}} \mathrm{Si}_{3}}$ & $0.398 * *$ & [11] \\
\hline & $\mathrm{X}_{\mathrm{Si}}^{\mathrm{Ti}_{\mathrm{i}} \mathrm{Si}_{4}}$ & 0.444 & {$[2-5]$} \\
\hline \multirow{4}{*}{$\mathrm{L}+\mathrm{Ti}_{5} \mathrm{Si}_{4}=\mathrm{TiSi}$} & $\mathrm{T}(\mathrm{K})$ & 1843 & {$[2-5]$} \\
\hline & $\mathrm{X}_{\mathrm{Si}}^{\mathrm{L}}$ & 0.60 & {$[2-5]$} \\
\hline & $\mathrm{X}_{\mathrm{Si}}^{\mathrm{TiS}_{\mathrm{Si}}}$ & 0.444 & {$[2-5]$} \\
\hline & $\mathrm{X}_{\mathrm{Si}}^{\mathrm{TiSi}}$ & 0.5 & {$[2-5]$} \\
\hline \multirow{4}{*}{$\beta+\mathrm{Ti}_{5} \mathrm{Si}_{3}=\mathrm{Ti}_{3} \mathrm{Si}$} & $\mathrm{T}(\mathrm{K})$ & 1443 & {$[5,11]$} \\
\hline & $\mathrm{X}_{\mathrm{Si}}^{\beta}$ & 0.04 & {$[5,11]$} \\
\hline & $\mathrm{X}_{\mathrm{Si}}^{\mathrm{Ti}_{\mathrm{i}} \mathrm{Si}_{3}}$ & $0.36^{* *}$ & [11] \\
\hline & $\mathrm{X}_{\mathrm{Si}}^{\mathrm{Ti}_{3} \mathrm{Si}}$ & 0.25 & {$[5,11]$} \\
\hline \multirow{4}{*}{$\beta=\alpha+\mathrm{Ti}_{3} \mathrm{Si}$} & $\mathrm{T}(\mathrm{K})$ & $1149 *$ & {$[2,5,11,24]$} \\
\hline & $\mathrm{X}_{\mathrm{Si}}^{\beta}$ & $0.009 *$ & {$[2,5,11,24]$} \\
\hline & $\mathrm{X}_{\mathrm{Si}}^{\alpha}$ & $0.004 *$ & {$[2,5,11,24]$} \\
\hline & $\mathrm{X}_{\mathrm{Si}}^{\mathrm{T}_{3} \mathrm{Si}}$ & 0.25 & {$[5,11]$} \\
\hline \multirow{4}{*}{$\beta=\alpha+\mathrm{Ti}_{5} \mathrm{Si}_{3}$} & $\mathrm{~T}(\mathrm{~K})$ & 1130 & {$[2-4,6-7]$} \\
\hline & $\mathrm{X}_{\mathrm{Si}}^{\mathrm{\beta}}$ & 0.011 & {$[2-4,6-7]$} \\
\hline & $\mathrm{X}_{\mathrm{si}}^{\alpha}$ & 0.005 & {$[2-4,6-7]$} \\
\hline & $\mathrm{X}_{\mathrm{Si}}^{\mathrm{Ti}_{\mathrm{i}} \mathrm{Si}_{3}}$ & 0.375 & {$[2-4,6-7]$} \\
\hline
\end{tabular}


Table 3: Enthalpy for the formation of the intermetallic phases of the Ti-Si system at $298 \mathrm{~K}(\mathrm{~kJ} / \mathrm{mol})$.

\begin{tabular}{cccccccc}
\hline $\mathrm{Ti}_{3} \mathrm{Si}$ & $\mathrm{Ti}_{5} \mathrm{Si}_{3}$ & $\mathrm{Ti}_{5} \mathrm{Si}_{4}$ & $\mathrm{TiSi}$ & $\mathrm{TiSi}_{2}$ & Type & Reference \\
\hline-50.0 & -72.67 & -79.0 & -77.76 & -57.036 & $\begin{array}{c}\text { Calculated by } \\
\text { optimization }\end{array}$ & {$[11]$} \\
-47.11 & -72.53 & -74.63 & -72.23 & -49.87 & $\begin{array}{c}\text { Ab-initio, } \mathrm{T}= \\
0 \mathrm{~K}\end{array}$ & {$[20]$} \\
- & -72.52 & - & - & - & Experimental & {$[25]$} \\
- & - & - & - & -56.97 & Experimental & {$[26]$} & {$[27]$} \\
- & -72.42 & - & - & - & Experimental & Experimental & {$[28]$} \\
- & -78.1 & -75.9 & -71.5 & -53.5 & - & Experimental & {$[29]$} \\
-49 & -73.8 & -78.5 & -72.6 & -55 & Experimental & {$[30]$} \\
\hline
\end{tabular}

Table 4: Calculated variables of $\mathrm{Ti}_{3} \mathrm{Si}$ and $\mathrm{Ti}_{5} \mathrm{Si}_{3}$ phases after optimization procedures. Vi1 in (J.(mol of atoms) $\left.{ }^{-1}\right)$; Vi2 and Vi3 in (J.(mol of atoms $\left.\left.)^{-1}\right) \cdot \mathrm{K}^{-1}\right)$. The value for the reduced sum of squares was equal to $10 \mathrm{for}$ both procedures. The values of the present investigation were compared with the values of the last assessment ${ }^{11}$.

\begin{tabular}{lcccc}
\hline Description & $\begin{array}{c}\text { Optimizing } \\
\text { variables }\end{array}$ & Calculated values & $\begin{array}{c}\text { Values of Seifert } \\
\text { et al. }{ }^{11}\end{array}$ & Difference (\%) \\
\hline \multirow{2}{*}{ Gibbs energy for the formation of $\mathrm{Ti}_{3} \mathrm{Si}_{5}$} & $\mathrm{~V} 11$ & -360707.460 & -206191.45 & 75 \\
& $\mathrm{~V} 12$ & 15.4134911 & 16.4953 & 7 \\
\hline \multirow{2}{*}{ Gibbs energy for the formation of $\mathrm{Ti}_{5} \mathrm{Si}_{3}$} & $\mathrm{~V} 21$ & -592931.498 & -583564.31 & 2 \\
\hline \multirow{2}{*}{ Gibbs energy for the formation of $\mathrm{Ti}_{6} \mathrm{Si}_{2}$} & $\mathrm{~V} 22$ & 3.78463760 & 2.68514 & 41 \\
\hline \multirow{2}{*}{ Excess Gibbs energy (*:Ti,Si:Ti) } & $\mathrm{V} 31$ & -141301.038 & 417375.85 & 134 \\
\hline \multirow{2}{*}{ Excess Gibbs energy (Si,Ti:*:Ti) } & $\mathrm{V} 32$ & 22.2273728 & 33.81017 & 34 \\
\hline & $\mathrm{V} 41$ & 47538.3043 & 43024.29 & 10 \\
Gibbs energy for the formation of $\mathrm{Ti}_{3} \mathrm{Si}$ & $\mathrm{V} 51$ & -4.64574985 & -3.44194 & -35 \\
\hline
\end{tabular}

Figure 3-a shows a general view of the calculated metastable Ti-Si phase diagram, indicating that the positions of the phase boundaries are in fair agreement with previous experimental results ${ }^{2-4}$. Figure 3-b shows a detail of the Tirich corner of the metastable Ti-Si phase diagram near the eutectoid reaction, $\operatorname{Ti}(\beta) \rightarrow \operatorname{Ti}(\alpha)+\mathrm{Ti}_{5} \mathrm{Si}_{3}$. The positions of the solvus lines and phase boundaries are in good agreement with previous experimental diagrams $s^{2-4,6-7}$. Figure $3-c$ compares the present assessment with the calculated Ti-Si phase diagram using COST 507 database $^{22}$. The present assessment shows lower values for the $\mathrm{Si}$ solubility in the $\operatorname{Ti}(\alpha)$ and $\operatorname{Ti}(\beta)$ phases, especially for the $\operatorname{Ti}(\beta)$ phase. Additionally, there is a significant difference in the inclination of the solvus line of the $\operatorname{Ti}(\alpha)$ phase: in the present assessment there is a reduction of the $\mathrm{Si}$ solubility in the $\mathrm{Ti}(\alpha)$ phase in lower temperatures, while in the version using COST 507 database there is an increase in the $\mathrm{Si}$ solubility in the $\mathrm{Ti}(\alpha)$ phase in lower temperatures. The present assessment of the metastable Ti-Si phase diagram shows a better agreement with the experimental results ${ }^{2-4,6-7}$ near the eutectoid region, $\mathrm{Ti}(\beta) \rightarrow \mathrm{Ti}(\alpha)+\mathrm{Ti}_{5} \mathrm{Si}_{3}$; and a more usual inclination of the $\operatorname{Ti}(\alpha)$ solvus line when compared with the assessed phase diagram using the COST 507 database ${ }^{22}$.
Figure 4-a compares the stable and metastable eutectoid reactions in the Ti-rich corner of the Ti-Si phase diagram obtained in the present investigation, indicating that the metastable diagram presents, as expected, an increase in the Si solubility in the $\operatorname{Ti}(\alpha)$ and $\operatorname{Ti}(\beta)$ phases and a decrease in the eutectoid temperature. Additionally, the $\mathrm{Ti}_{5} \mathrm{Si}_{3}$ phase in equilibrium with $\mathrm{Ti}_{3} \mathrm{Si}$ phase shows a slightly narrower range of Si solubility below the eutectic temperature, indicating higher $\mathrm{Si}$ solubility of the $\mathrm{Ti}_{5} \mathrm{Si}_{3}$ phase in equilibria with $\mathrm{Ti}(\beta)$ and $\mathrm{Ti}_{3} \mathrm{Si}$ phases (see Figure 4-b).

It is worth mentioning that most experimental works on the Ti-Si and Ti-Si-X systems ${ }^{1-5,12-20}$ did not perform chemical analysis of the samples after long isothermal heat-treatments to insure the lack of interstitial contamination. Some of these works, however, were careful enough to apply hardness measurements of control samples (before and after heat-treatments) to audit possible and critical interstitial contamination during the experimental work ${ }^{1-4,6-7,12-14}$. Some of the disagreements found in the literature about on the presence of the $\mathrm{Ti}_{3} \mathrm{Si}$ in the $\mathrm{Ti}-\mathrm{Si}$ and Ti-X-Si phase diagrams might be explained by the occurrence of interstitial contamination ${ }^{1}$, as the presence of interstitials might promote the stability of the $\mathrm{Ti}_{3} \mathrm{Si}$ phase ${ }^{1,6-7,11}$. In the classical work of Svechnikov et al. ${ }^{5}$, for instance, they observed the presence of a $\mathrm{Ti}(\beta)+\mathrm{Ti}_{5} \mathrm{Si}_{3}+\mathrm{Ti}_{3} \mathrm{Si}$ phases instead of $\mathrm{Ti}(\beta)+$ 
Table 5: Experimental and calculated equilibrium for the "stable" and "metastable" Ti-Si phase diagrams. Deviations between experimental and calculated values above $5 \%$ were marked with (*).

\begin{tabular}{|c|c|c|c|c|}
\hline Reaction & Parameter & Experimental & Calculated & Deviation $(\%)$ \\
\hline \multirow{2}{*}{$\mathrm{L} \rightarrow \mathrm{Ti}_{5} \mathrm{Si}_{3}$} & $\mathrm{~T}(\mathrm{~K})$ & 2403 & 2441 & 1.6 \\
\hline & $\mathrm{X}^{\mathrm{Si}}\left(\mathrm{Ti}_{5} \mathrm{Si}_{3}\right)$ & 0.375 & 0.376 & 0.3 \\
\hline \multirow{2}{*}{$\mathrm{L} \rightarrow \mathrm{TiSi}_{2}$} & $\mathrm{~T}(\mathrm{~K})$ & 1773 & 1757 & 0.9 \\
\hline & $\mathrm{X}^{\mathrm{Si}}\left(\mathrm{TiSi}_{2}\right)$ & 0.667 & 0.667 & 0 \\
\hline \multirow{4}{*}{$\mathrm{L} \rightarrow \beta+\mathrm{Ti}_{5} \mathrm{Si}_{3}$} & $\mathrm{~T}(\mathrm{~K})$ & 1613 & 1638 & 1.6 \\
\hline & $\mathrm{X}^{\mathrm{Si}}(\mathrm{L})$ & 0.137 & 0.124 & $9.5^{*}$ \\
\hline & $\mathrm{X}^{\mathrm{Si}}(\beta)$ & 0.05 & 0.04 & $20 *$ \\
\hline & $\mathrm{X}^{\mathrm{Si}}\left(\mathrm{Ti}_{5} \mathrm{Si}_{3}\right)$ & 0.36 & 0.356 & 1.1 \\
\hline \multirow{4}{*}{$\mathrm{L} \rightarrow \mathrm{TiSi}_{2}+\mathrm{Si}$} & $\mathrm{T}(\mathrm{K})$ & 1603 & 1604 & 0.1 \\
\hline & $\mathrm{X}^{\mathrm{Si}}(\mathrm{L})$ & 0.86 & 0.815 & $5.2^{*}$ \\
\hline & $\mathrm{X}^{\mathrm{Si}}\left(\mathrm{TiSi}_{2}\right)$ & 0.667 & 0.667 & 0 \\
\hline & $\mathrm{X}^{\mathrm{Si}}(\mathrm{Si})$ & 1 & 1 & 0 \\
\hline \multirow{4}{*}{$\mathrm{L} \rightarrow \mathrm{TiSi}_{2}+\mathrm{TiSi}$} & $\mathrm{T}(\mathrm{K})$ & 1743 & 1747 & 0.2 \\
\hline & $\mathrm{X}^{\mathrm{Si}}(\mathrm{L})$ & 0.641 & 0.637 & 0.6 \\
\hline & $\mathrm{X}^{\mathrm{Si}}(\mathrm{TiSi})$ & 0.5 & 0.5 & 0 \\
\hline & $\mathrm{X}^{\mathrm{Si}}\left(\mathrm{TiSi}_{2}\right)$ & 0.667 & 0.667 & 0 \\
\hline \multirow{4}{*}{$\mathrm{L}+\mathrm{Ti}_{5} \mathrm{Si}_{3} \rightarrow \mathrm{Ti}_{5} \mathrm{Si}_{4}$} & $\mathrm{~T}(\mathrm{~K})$ & 2193 & 2172 & 1.0 \\
\hline & $\mathrm{X}^{\mathrm{Si}}(\mathrm{L})$ & 0.48 & 0.503 & 4.8 \\
\hline & $\mathrm{X}^{\mathrm{Si}}\left(\mathrm{Ti}_{5} \mathrm{Si}_{3}\right)$ & 0.398 & 0.394 & 1.0 \\
\hline & $\mathrm{X}^{\mathrm{Si}}\left(\mathrm{Ti}_{5} \mathrm{Si}_{4}\right)$ & 0.444 & 0.444 & 0 \\
\hline \multirow{4}{*}{$\mathrm{L}+\mathrm{Ti}_{5} \mathrm{Si}_{4} \rightarrow \mathrm{TiSi}$} & $\mathrm{T}(\mathrm{K})$ & 1843 & 1843 & 0 \\
\hline & $\mathrm{X}^{\mathrm{Si}}(\mathrm{L})$ & 0.60 & 0.604 & 0.7 \\
\hline & $\mathrm{X}^{\mathrm{Si}}\left(\mathrm{Ti}_{5} \mathrm{Si}_{4}\right)$ & 0.444 & 0.444 & 0 \\
\hline & $\mathrm{X}^{\mathrm{Si}}(\mathrm{TiSi})$ & 0.5 & 0.5 & 0 \\
\hline \multirow{4}{*}{$\beta+\mathrm{Ti}_{5} \mathrm{Si}_{3} \rightarrow \mathrm{Ti}_{3} \mathrm{Si}$} & $\mathrm{T}(\mathrm{K})$ & 1443 & 1443 & 0 \\
\hline & $\mathrm{X}^{\mathrm{Si}}(\beta)$ & 0.04 & 0.028 & $30 *$ \\
\hline & $\mathrm{X}^{\mathrm{Si}}\left(\mathrm{Ti}_{5} \mathrm{Si}_{3}\right)$ & 0.36 & 0.359 & 0.3 \\
\hline & $\mathrm{X}^{\mathrm{Si}}\left(\mathrm{Ti}_{3} \mathrm{Si}\right)$ & 0.25 & 0.25 & 0 \\
\hline \multirow{4}{*}{$\beta \rightarrow \alpha+\mathrm{Ti}_{3} \mathrm{Si}$} & $\mathrm{T}(\mathrm{K})$ & 1149 & 1143 & 0.5 \\
\hline & $\mathrm{X}^{\mathrm{Si}}(\beta)$ & 0.009 & 0.0088 & 2.2 \\
\hline & $X^{S i}(\alpha)$ & 0.004 & 0.0037 & $7.5^{*}$ \\
\hline & $\mathrm{X}^{\mathrm{Si}}\left(\mathrm{Ti}_{5} \mathrm{Si}_{3}\right)$ & 0.25 & 0.25 & 0 \\
\hline \multirow{4}{*}{$\beta \rightarrow \alpha+\mathrm{Ti}_{5} \mathrm{Si}_{3}$} & $\mathrm{~T}(\mathrm{~K})$ & 1130 & 1140 & 0.9 \\
\hline & $X^{\mathrm{Si}}(\beta)$ & 0.011 & 0.0114 & 3.7 \\
\hline & $X^{S i}(\alpha)$ & 0.005 & 0.0048 & 4.0 \\
\hline & $\mathrm{X}^{\mathrm{Si}}\left(\mathrm{Ti}_{5} \mathrm{Si}_{3}\right)$ & 0.375 & 0.3651 & 2.7 \\
\hline
\end{tabular}

Table 6: Calculated values of the enthalpy (kJ/mol of atoms) and entropy (J/mol.K) of the formation of the intermetallic phases at 298 $\mathrm{K}$ - present work - compared with values of enthalpy found in the literature ${ }^{11,20,25-30}$.

\begin{tabular}{lcccc}
\hline Phase & $\begin{array}{c}\text { Average values of } \\
\text { the enthalpy in the } \\
\text { literature }\end{array}$ & $\begin{array}{c}\text { Ab-initio values of } \\
\text { enthalpy }\end{array}$ & $\begin{array}{c}\text { Calculated values of } \\
\text { enthalpy (kJ/mol of atoms) }\end{array}$ & $\begin{array}{c}\text { Calculated values of entropy } \\
(\mathrm{J} / \mathrm{mol} . \mathrm{K})\end{array}$ \\
\hline $\mathrm{Ti}_{3} \mathrm{Si}$ & -49.5 & -47.11 & -47.57 & 31.33 \\
$\mathrm{Ti}_{5} \mathrm{Si}_{3}$ & -73.9 & -72.53 & -74.12 & 25.78 \\
$\mathrm{Ti}_{5} \mathrm{Si}_{4}$ & -77.8 & -74.63 & -79.03 & 22.94 \\
$\mathrm{TiSi}$ & -74.0 & -72.23 & -77.53 & 20.94 \\
$\mathrm{TiSi}_{2}$ & -55.8 & -49.87 & -58.35 & 21.26 \\
\hline
\end{tabular}




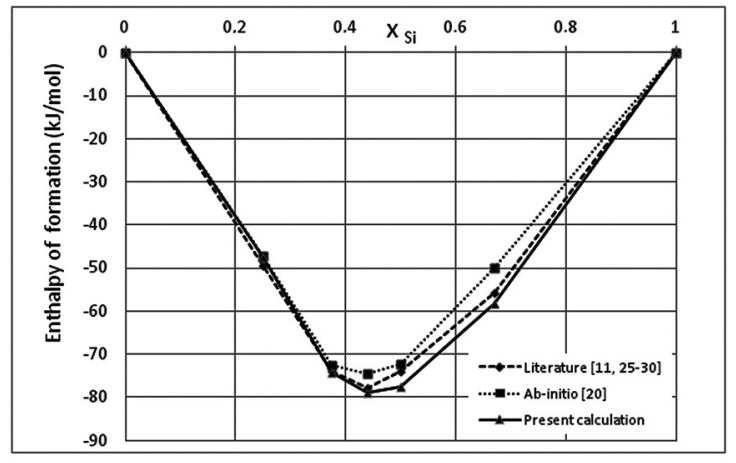

(a)

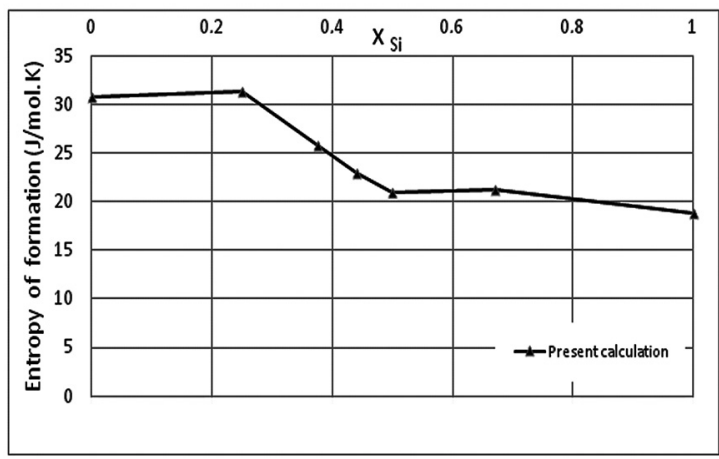

(b)

Figure 1: a) Enthalpies for the formation of the Si-Ti compounds, comparing the calculated results of the present work with the values found in the literature ${ }^{11,20,25-30}$; b) Entropies for the formation of the Si-Ti compounds.

$\mathrm{Ti}_{5} \mathrm{Si}_{3}$ phases after heat-treatment at $1493 \mathrm{~K}$ for $120 \mathrm{~h}$ of Ti-Si alloys with Si contents below 25 at $\% \mathrm{Si}$, see Figure 2. This observation might suggest some interstitial contamination of the alloys during the experimental work of Svechnikov et al. ${ }^{5}$. Discrepancies were also observed in the investigation by Ramos et al. ${ }^{16}$, which showed the presence of $\mathrm{Ti}_{5} \mathrm{Si}_{3}$ phase instead of $\mathrm{Ti}_{3} \mathrm{Si}$ phase after isothermal heat-treatment for 90 hours at $1273 \mathrm{~K}$ and $1373 \mathrm{~K}$ of a Ti-25Si alloy, see Figure 2. Similarly, Costa et al. ${ }^{17}$ showed the presence of $\operatorname{Ti}(\alpha)+\mathrm{Ti}_{3}$ Si phases instead of $\mathrm{Ti}(\beta)+\mathrm{Ti}_{3} \mathrm{Si}$ phases after isothermal treatment for 6 hours at $1273 \mathrm{~K}$ of a Ti-13Si alloy, see Figure 2. These examples support previous suggestions made by Aaronson et al., "that further experimental work in the Ti-rich corner of the Ti-Si system is needed" to explain experimental disparities, especially near the eutectoid region of the Ti-rich corner of the Ti-Si phase diagram; and that "some of these experimental discrepancies could explained by interstitial contamination".

More recently, Colinet and Tedenac ${ }^{20}$ indicated by ab-initio calculations that the question of the stability of the $\mathrm{Ti}_{3} \mathrm{Si}$ phase was in fact "controversial"; while Poletaev et al. ${ }^{21}$ showed by ab-initio calculations that the $\mathrm{Ti}_{5} \mathrm{Si}_{3}$ phase was essentially more stable than the $\mathrm{Ti}_{3} \mathrm{Si}$ phase at $0 \mathrm{~K}$, adding a new light on the dispute over the stability of $\mathrm{Ti}_{3} \mathrm{Si}$ phase in the Ti-Si and Ti-X-Si systems. In this sense, the present assessments aim to inspire further experimental work in the eutectoid region of the Ti-rich corner of the Ti-Si phase diagram in order to investigate the stability of $\mathrm{Ti}_{3} \mathrm{Si}$ and $\mathrm{Ti}_{5} \mathrm{Si}_{3}$ phases; and the effect of interstitials on the stability of the $\mathrm{Ti}_{3} \mathrm{Si}$ phase. The microstructural design of

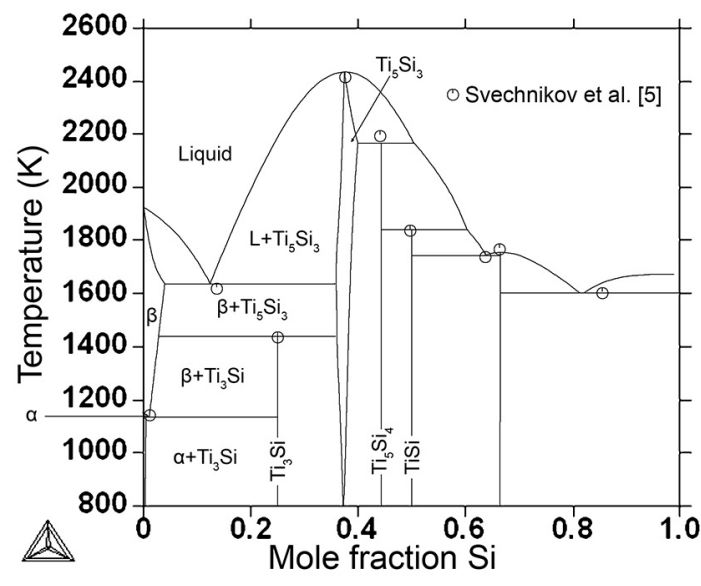

(a)

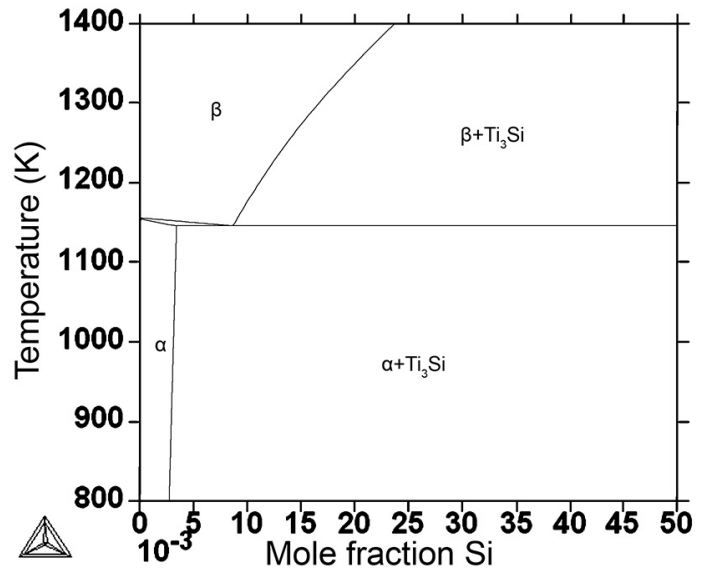

(b)

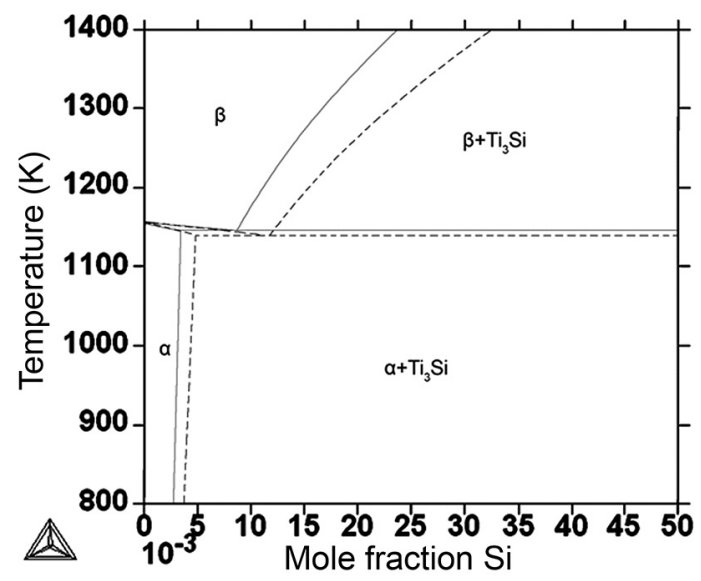

(c)

Figure 2: Assessed "stable" Ti-Si phase diagram. a) General view of the phase diagram, $\left(\beta+\mathrm{Ti}_{5} \mathrm{Si}_{3} \rightarrow \mathrm{Ti}_{3} \mathrm{Si}\right.$ and $\beta \rightarrow \alpha+\mathrm{Ti}_{3} \mathrm{Si}$ reactions); b) Detail of the eutectoid reaction, $\operatorname{Ti}(\beta) \rightarrow \mathrm{Ti}(\alpha)+\mathrm{Ti}_{3} \mathrm{Si}$, in the Ti-rich corner; c) Comparison between the present assessment and assessment (dotted lines) using COST 507 database $^{22}$.

commercial Ti-X-Si alloys requires the presence of enough $\mathrm{Si}$ in solid solution in the matrix to improve the oxidation resistance; and the precipitation of "strong" Ti-Si intermetallics, which 


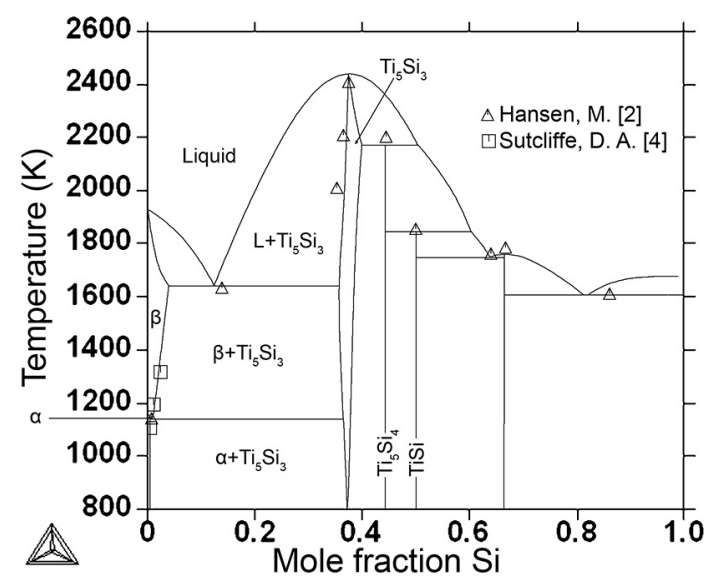

(a)

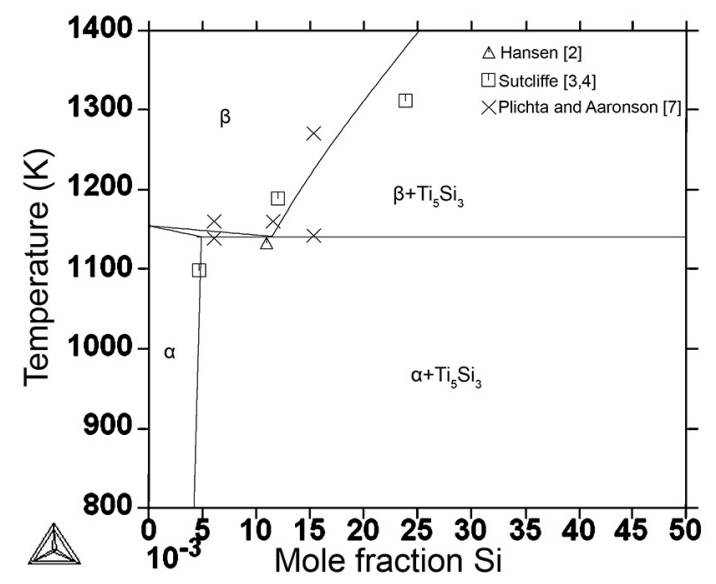

(b)

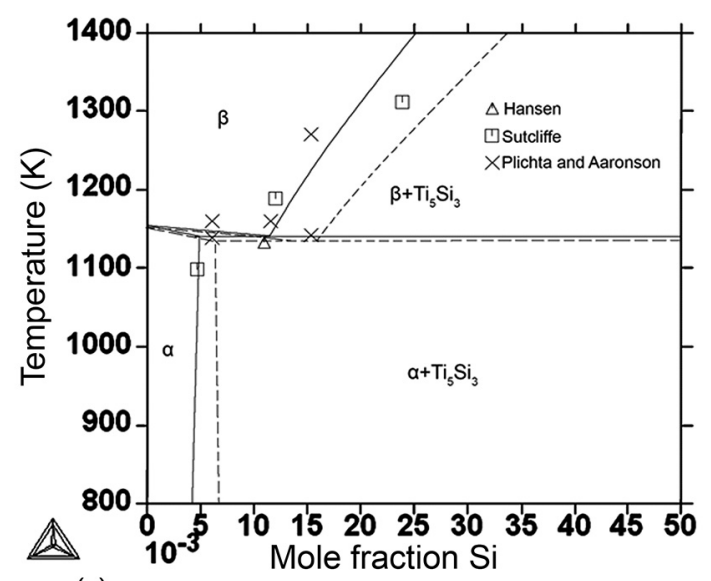

(c)

Figure 3: Assessed "metastable" Ti-Si phase diagram. a) General view of the Ti-Si phase diagram; b) Detail of the eutectoid reaction, $\mathrm{Ti}(\beta) \rightarrow \operatorname{Ti}(\alpha)+\mathrm{Ti}_{5} \mathrm{Si}_{3}$, in the Ti-rich corner; c) Comparison between the present assessment and assessment (dotted lines) using COST 507 database ${ }^{22}$ with suspended $\mathrm{Ti}_{3} \mathrm{Si}$ phase.

must be stable at service temperatures, to improve the creep resistance ${ }^{1,21,32-36}$, so a better understanding of the Ti-rich corner of the Ti-Si phase diagram is needed.

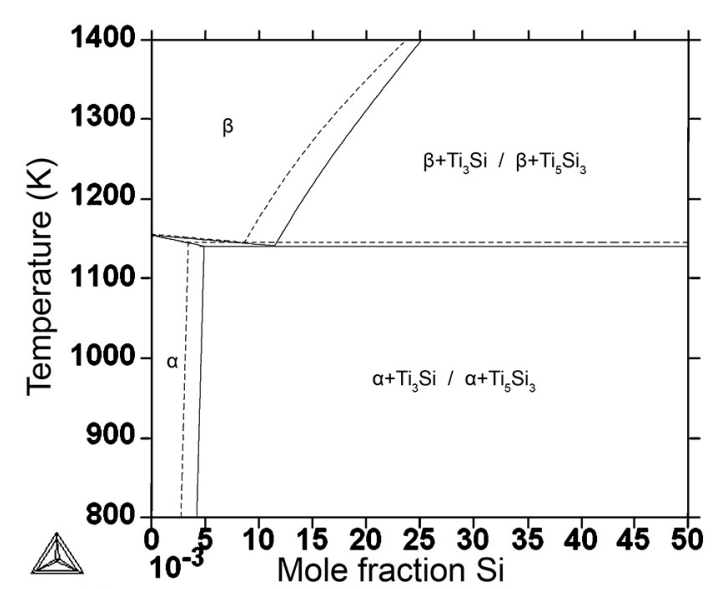

(a)

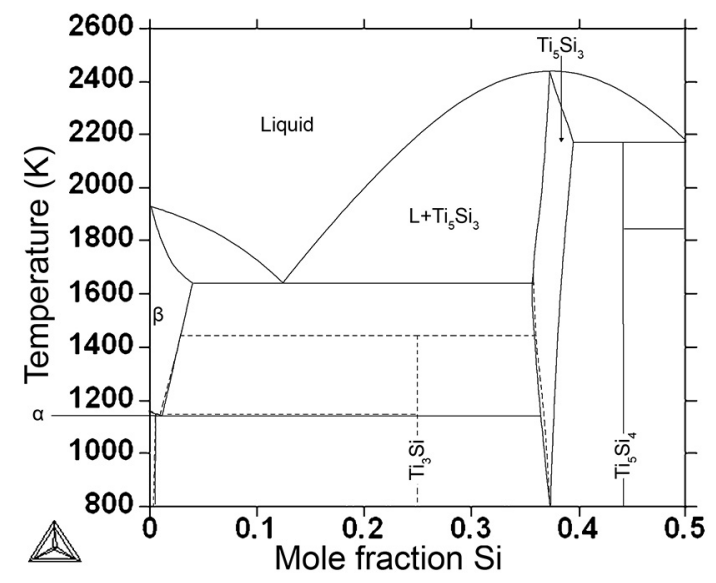

(b)

Figure 4: Comparison of the calculated stable (dotted lines) and metastable Ti-Si phase diagrams in the present investigation. a) Detail of the eutectoid reaction; b) Detail of the Si-solubility range of the $\mathrm{Ti}_{5} \mathrm{Si}_{3}$ phase.

\section{Conclusions}

Available experimental data allowed the calculation of the stable and metastable phase diagrams of the Ti-rich corner of the Ti-Si system.

The present assessment might be further improved by the use of a more complex description for the liquid phase and, more importantly, by the use of new experimental data near the eutectoid reaction of the Ti-rich corner of the Ti-Si phase diagram.

The present assessment of the "metastable" Ti-Si phase diagram showed a better agreement with the experimental results near the eutectoid region, $\mathrm{Ti}(\beta) \rightarrow \mathrm{Ti}(\alpha)+\mathrm{Ti}_{5} \mathrm{Si}_{3}$, and a more usual inclination of the Ti $(\alpha)$ solvus, when compared to the assessment using COST 507 database.

Further experimental work near the eutectoid region of the Ti-rich corner of the Ti-Si phase diagram is needed to solve the dispute over the stability of the $\mathrm{Ti}_{3} \mathrm{Si}$ and $\mathrm{Ti}_{5} \mathrm{Si}_{3}$ phases.

\section{Acknowledgments}

The authors would like to thank the kind collaboration of Prof. V. Pastoukhov, Prof. C.G. Schöen, Prof. L.T.F Eleno and 
Prof. S. Wolynec, all from Universidade de São Paulo, and Dr. A. H. Feller. This work is dedicated to the memories of Mr. A. C. Azevedo, Prof. H. M. Flower (Imperial College) and Mrs. B. F. Feller. The present investigation was funded by the Ministry of Education from Brazil (Coordination for the Improvement of Higher Education Personnel, CAPES) in a form of a MEng scholarship to Ms. M. Fiore.

\section{References}

1. Azevedo CRF. Phase Diagram and Phase Transformations in Ti-AlSi System [PhD Thesis]. London: Imperial College, Department of Materials; 1996.

2. Hansen M, Anderko K. Constitutions of binary alloys. New York, Toronto, London: McGraw-Hill; 1958.

3. Sutcliffe DA. Alliage de titane et de silicium. Revue de Metallurgie. 1954;3:524-536.

4. Sutcliffe DA. Titanium-Silicon Alloys. Metal Treatment and Drop Forging. 1954;4:181-197.

5. Svechnikov VN, Kocherzhisky YA, Yupko LM, Kulik OG, Shinshkin EA. Phase Diagram of the Titanium-Silicon System. Doklady Akademii Nauk SSSR. 1970;193(2):393-396.

6. Plichta MR, Williams JC, Aaronson HI. On the existence of the $\beta \rightarrow \alpha_{\mathrm{m}}$ transformation in the alloy systems Ti-Ag, Ti-Au, and Ti-Si. Metallurgical and Materials Transactions A. 1977;8(12):1885-1892.

7. Plitcha MR, Aaronson HI. The thermodynamic and kinetics of the $\beta->a_{m}$ transformation in three Ti-X systems. Acta Metallurgica. 1978;26(8):1293-1305.

8. Kauffman L. Coupled phase diagrams and thermochemical data for transition metal binary systems-VI. Calphad. 1970;3(1):45-76.

9. Murray JL. Phase diagrams of titanium binary alloys. Novelty: ASM International:; 1987. p.289-293.

10. Vahlas C, Chevalier PY, Blanquet E. A Thermodynamic Evaluation of Four Si-M (M=Mo, Ta, Ti, W) Binary System. Calphad. 1989;13(3):273-292.

11. Seifert HJ, Lukas HL, Petzow G. Thermodynamic Optimization of the Ti-Si system. Zeitschrift für Metallkunde. 1996;87(1):2-13.

12. Azevedo CRF, Flower HM. Microstructure and phase relationships in Ti-Al-Si system. Materials Science and Technology. 1999;15(8):869-877.

13. Azevedo CRF, Flower HM. Experimental and calculated Ti-rich Corner of the Ti-Al-Si Ternary Phase Diagram. Calphad. 2002;26(3):353-373.

14. Azevedo CRF, Flower HM. Calculated ternary diagram of Ti-Al-Si system. Materials Science and Technology. 2000;16(4):372-381.

15. Bulanova M, Tretyachanko L, Golovkova M. Phase Equilibria in the Ti-rich corner of the Ti-Al-Si System. Zeitschrift für Metallkunde. 1997;88(3):256-265.

16. Ramos AS, Nunes CA, Coelho GC. On the peritectoid $\mathrm{Ti}_{3} \mathrm{Si}$ formation in Ti-Si alloys. Materials Characterization. 2006;56:107-111.

17. Costa AMS, Lima GF, Rodrigues G, Nunes CA, Coelho GC, Suzuki PA. Evaluation of $\mathrm{Ti}_{3} \mathrm{Si}$ phase stability from heat-treated rapidly solidified Ti-Si alloys. Journal of Phase Equilibria and Diffusion. 2010;31(1):22-27.

18. Li Z, Liao C, Liu Y, Wang X, Wu Y, Zhao M, et al. $700^{\circ} \mathrm{C}$ Isothermal Section of the Al-Ti-Si Ternary Phase Diagram. Journal of Phase Equilibria and Diffusion. 2014;35(5):564-574.

19. Kozlov AY, Pavlyuk VV. Investigation of the interaction between the components in the $\mathrm{Ti}-\{\mathrm{Si}, \mathrm{Ge}\}-\mathrm{Sb}$ systems at $670 \mathrm{~K}$. Journal of Alloys and Compounds. 2004;367(1-2):76-79.
20. Colinet C, Tedenac JC. Structural stability of intermetallic phases in the Si-Ti system. Point defects and chemical potentials in $\mathrm{D}_{8}{ }_{8} \mathrm{Si}_{3} \mathrm{Ti}_{5}$ phase. Intermetallics. 2010;18(8):1444-1454.

21. Poletaev DO, Lipnitskii AG, Kartamyshev AI, Aksyonov DA, Tkachev ES, Manokhin SS, et al. Ab initio-based prediction and TEM study of silicide precipitation in titanium. Computational Materials Science. 2014;95:456-463.

22. European Cooperation in the Field of Scientific and Technical Research, European Commission. COST 507 - Definition of thermochemical and thermophysical properties to provide a database for the development of new light alloys. Vol 1. Proceedings of the Final Workshop of COST 507, Vaals; 1997. Luxembourg: Office for Official Publications of the European Communities; 1998. Vol 2. Ansara I, Dinsdale AT, Rand MH, eds. Thermochemical Database for Light Metal Alloys Luxembourg: Office for Official Publications of the European Communities; 1998. Vol 3. Effenberg G, ed. Critical Evaluation of Ternary Systems. Luxembourg: Office for Official Publications of the European Communities; 1998.

23. Lukas HL, Fries SG, Sundman B. Computational Thermodynamics: The Calphad Method. Cambridge: Cambridge University Press; 2007.

24. Okamoto H. The C-Fe (carbon-iron) System. Journal of Phase Equilibria. 1992;13(5):543-565.

25. Robins DA, Jenskins I. The heats of formation of some transition metal silicides. Acta Metallurgica. 1955;3(6):598-604.

26. Topor L, Kleppa OJ. Standard enthalpies of formation of $\mathrm{TiSi}_{2}$ and $\mathrm{VSi}_{2}$ by high-temperature calorimetry. Metallurgical and Materials Transactions A. 1986;17(7):1217-1221.

27. Maslov VM, Neganov AS, Borovinskaya IP, Merzhanov AG. Selfpropagating high-temperature synthesis as a method for determination of the heat of formation of refractory compounds. Combustion, Explosion and Shock Waves. 1978;14(6):759-767.

28. Kematick RJ, Myers CE. Thermodynamics of the Phase Formation of the Titanium Silicides. Chemistry of Materials. 1996;8(1):287-291.

29. Meschel SV, Kleppa OJ. Standard enthalpies of formation of some $3 \mathrm{~d}$ transition metal silicides by high temperature direct synthesis calorimetry. Journal of Alloys and Compounds. 1998;267(1-2):128-135.

30. Coelho GC, David N, Gachon JC, Nunes CA, Fiorani JM, Vilasi M. Entalpias de formação de fases intermetálicas dos sistemas Ti-Si, Ti-B e Ti-Si-B medidas por calorimetria de síntese direta. In: Associação Brasileira de Metalurgia e Materiais. Anais do $61^{\circ}$ congresso Anual da ABM. Rio de Janeiro, Brasil. São Paulo: ABM; 2006. p. 1300-1308

31. Thermo-Calc Data optimization User Guide, Version 2015a. Foundation of Computational Thermodynamics Stockholm, Sweden. [Accessed: 2015 Nov 15]. Available from: http://www.thermocalc.com/ media/30890/Data-Optimisation-User-Guide-for-Thermo-Calc.pdf

32. Frommeyer G, Rosenkranz R, Lüdecke C. Microstructure and properties of the refractory intermetallic $\mathrm{Ti}_{5} \mathrm{Si}_{3}$ compound and the unidirectionally solidified eutectic $\mathrm{Ti}-\mathrm{Ti}_{5} \mathrm{Si}_{3}$ alloy. Zeitschrift für Metallkunde. 1990;81:307-313.

33. Zhang L, Wu J. Ti $\mathrm{Si}_{5}$-based alloys: alloying behavior, microstructure and mechanical property evaluation. Acta Materialia. 1998;46(10):3535-3546.

34. Kishida K, Fujiwara M, Adachi H, Tanaka K, Inui H. Plastic deformation of single crystals of $\mathrm{Ti}_{5} \mathrm{Si}_{3}$ with the hexagonal $\mathrm{D}_{8}$ structure. Acta Materialia. 2010;58(3):846-857.

35. Williams JJ. Structure and high-temperature properties of Ti5Si3 with interstitial additions [PhD Thesis]. Iowa: Iowa State University; 1999.

36. Kastenhuber M, Rashkova B, Clemens H, Mayer S. Enhancement of creep properties and microstructural stability of intermetallic $\beta$-solidifying $\gamma$-TiAl based alloys. Intermetallics. 2015;63:19-26. 
Annex 1: Thermodynamic description of the phases of the Ti-Si system

\section{LIQUID}

EXCESS MODEL IS REDLICH-KISTER_MUGGIANU

CONSTITUENTS: SI,TI

G(LIQUID,SI;0)-H298(DIAMOND_A4,SI;0) =

$298.15<\mathrm{T}<1687.00:+50696.4-30.0994 * \mathrm{~T}+2.09307 \mathrm{E}-21 * \mathrm{~T} * * 7+$ GHSERSI

$1687.00<\mathrm{T}<6000.00:+49828.2-29.5591 * \mathrm{~T}+4.20369 \mathrm{E}+30 * \mathrm{~T} * *(-9)+$ GHSERSI

G(LIQUID,TI;0)-H298(HCP_A3,TI;0) =

298.15<T< 1300.00: +12194.415-6.980938*T+GHSERTI

1300.00<T<1941.00: +368610.36-2620.99904*T+357.005867*T*LN(T)-.155262855*T*2+1.2254402E-05*T**3-65556856*T**(-1)+GHSERTI 1941.00<T<6000.00: +104639.72-340.070171*T+40.9282461*T*LN(T)-.008204849*T*2+3.04747E-07*T**3-36699805*T**(-1)+GHSERTI L(LIQUID,SI,TI;0) $=-255852.17+21.87411 * \mathrm{~T}$

L(LIQUID,SI,TI;1) $=+25025.35-2.00203 * \mathrm{~T}$

L(LIQUID,SI,TI;2) $=+83940.65-6.71526 * \mathrm{~T}$

BCC_A2

EXCESS MODEL IS REDLICH-KISTER_MUGGIANU

2 SUBLATTICES, SITES 1: 3

CONSTITUENTS: SI,TI: VA

G(BCC_A2,SI:VA;0)-H298(DIAMOND_A4,SI;0) $=+47000-22.5 * \mathrm{~T}+\mathrm{GHSERSI}$

G(BCC_A2,TI:VA;0)-H298(HCP_A3,TI;0) =

298.15<T< 1155.00: $-1272.064+134.71418 * \mathrm{~T}-25.5768 * \mathrm{~T} * \mathrm{LN}(\mathrm{T})$

$-6.63845 \mathrm{E}-04 * \mathrm{~T} * * 2-2.78803 \mathrm{E}-07 * \mathrm{~T} * * 3+7208 * \mathrm{~T} * *(-1)$

$1155.00<\mathrm{T}<1941.00:+6667.385+105.366379 * \mathrm{~T}-22.3771 * \mathrm{~T} * \mathrm{LN}(\mathrm{T})+$

$.00121707 * \mathrm{~T} * 2-8.4534 \mathrm{E}-07 * \mathrm{~T} * 3-2002750 * \mathrm{~T} * *(-1)$

1941.00<T<4000.00: $+26483.26-182.426471 * \mathrm{~T}+19.0900905 * \mathrm{~T} * \mathrm{LN}(\mathrm{T})$

$-.02200832 * \mathrm{~T} * 2+1.228863 \mathrm{E}-06 * \mathrm{~T} * * 3+1400501 * \mathrm{~T} * *(-1)$

L(BCC_A2,SI,TI:VA;0) $=-275629.1+42.5094 * \mathrm{~T}$

L(BCC_A2,SI,TI:VA;1) $=+25025.35-2.00203 * \mathrm{~T}$

L(BCC_A2,SI,TI:VA;2) $=+83940.65-6.71526 * \mathrm{~T}$

\section{DIAMOND_A4}

EXCESS MODEL IS REDLICH-KISTER_MUGGIANU

CONSTITUENTS: SI,TI

G(DIAMOND_A4,SI;0)-H298(DIAMOND_A4,SI;0) = +GHSERSI

G(DIAMOND_A4,TI;0)-H298(HCP_A3,TI;0) $=+25000+$ GHSERTI

L(DIAMOND_A4,SI,TI;0) $=+80 * \mathrm{~T}$

\section{HCP_A3}

EXCESS MODEL IS REDLICH-KISTER_MUGGIANU

2 SUBLATTICES, SITES 1:.5

CONSTITUENTS: SI,TI : VA

G(HCP_A3,SI:VA;0)-H298(DIAMOND_A4,SI;0) $=+49200-20.8 * T+$ GHSERSI

G(HCP_A3,TI:VA;0)-H298(HCP_A3,TI;0) = +GHSERTI

L(HCP_A3,SI,TI:VA;0) $=-302731.04+69.08469 * \mathrm{~T}$

L(HCP_A3,SI,TI:VA;1) $=+25025.35-2.00203 * \mathrm{~T}$

L(HCP_A3,SI,TI:VA;2) $=+83940.65-6.71526 * \mathrm{~T}$

SI2TI

2 SUBLATTICES, SITES 2: 1

CONSTITUENTS: SI: TI

G(SI2TI,SI:TI;0)-2*H298(DIAMOND_A4,SI;0)-H298(HCP_A3,TI;0) =

$-175038.5+4.548 * \mathrm{~T}+\mathrm{GHSERTI}+2 *$ GHSERSI 


\section{Continued Annex 1}

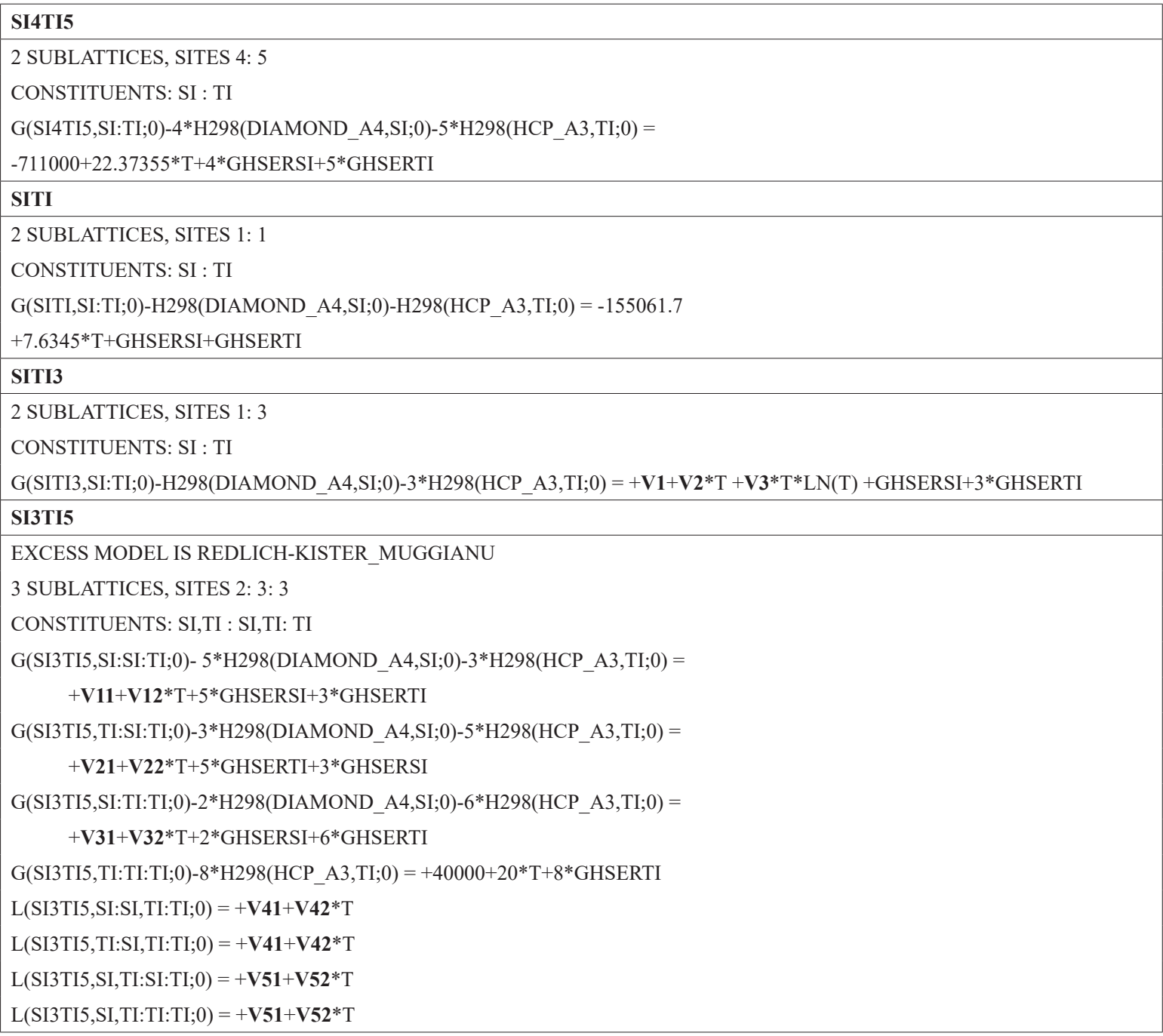

